\title{
Historical Analysis of the Example of Nowy Sącz in Space Syntax Perspective. Guidelines for Future Development of Urban Matrix in Medium-Sized Cities
}

\author{
Filip Suchoń ${ }^{1, *}$ and Justyna Olesiak ${ }^{2}$ (D) \\ 1 Urbanism and City Structure Architecture, Faculty of Architecture, Cracow University of Technology, \\ 31-155 Kraków, Poland \\ 2 Discipline Architecture and Urban Sciences, Doctoral School of Cracow University of Technology, \\ 31-155 Kraków, Poland; justyna.olesiak@gmail.com \\ * Correspondence: filip.suchon@pk.edu.pl
}

check for updates

Citation: Suchoń, F.; Olesiak, J. Historical Analysis of the Example of Nowy Sacz in Space Syntax

Perspective. Guidelines for Future Development of Urban Matrix in Medium-Sized Cities. Sustainability 2021, 13, 11071. https://doi.org/ $10.3390 /$ su131911071

Academic Editors: Claudia Yamu, Akkelies Van Nes and Chiara Garau

Received: 13 August 2021

Accepted: 29 September 2021

Published: 7 October 2021

Publisher's Note: MDPI stays neutral with regard to jurisdictional claims in published maps and institutional affiliations.

Copyright: (c) 2021 by the authors. Licensee MDPI, Basel, Switzerland. This article is an open access article distributed under the terms and conditions of the Creative Commons Attribution (CC BY) license (https:/ / creativecommons.org/licenses/by/ $4.0 /)$.

\begin{abstract}
This paper presents the development of the public space of Nowy Sacz, taking into account the space syntax analysis of the historical maps of the city and the structure of its development. Nowy Sacz is a city located in southern Poland, with over 80,000 residents. A space syntax analysis of historical maps helps to explain the urban space's growth and development structure. The scientific goal of this paper was to build model solutions and urban typologies of Nowy Sacz; to present the logic of the model; and to compare simulation results with reality and historical knowledge. The application goal was to explain the processes and popularize the insight using clear space syntax visualizations. Axial maps of street networks were developed using current and historical city plans (publicly available plans from the late 18th century to the present day). The space syntax methodology was employed to measure Integration and Choice variables for each stage of the city's spatial development. The results indicating areas of the highest Integration value were verified against historical studies. A strong correlation was demonstrated between the foci of urban life of super-local reach and their places in a growing city's structural network.
\end{abstract}

Keywords: heritage urbanism; space syntax; data-informed planning; urban transformations; middle-sized city; urban growth; Nowy Sacz

\section{Introduction}

Public open spaces are the most critical areas of modern cities striving for dynamic development. The growing problems faced by these cities make them more difficult. The uncontrolled urban sprawl accompanied by an inefficient transport system is the most severe threat. The most significant worth of a modern urban center is its identity, and chaotic development is a cause of its disappearance. The culture of a place and its history are timeless values that distinguish a city from others.

Most often, public open spaces are the elements that shape the individual character of a city. They concentrate on essential functions and, at the same time, influence its image. The elements of public open spaces, composition, configuration, and interactions between them, together form the urban matrix [1]. This paper presents an analysis of the development of an urban matrix in a medium-sized city-Nowy Sacz, Poland. These analyses enabled us to observe changes in these spaces' development, management, functioning, and the town itself.

Nowy Sacz can be considered a growth center that influences the socio-economic activity within its borders and neighboring areas. It is the third most important city in the Malopolska region in terms of scale of influence, after Krakow and Tarnow. It concentrates in its range a functional area at the supra-local level, with almost 300,000 residents. The tourist potential is based on the high natural assets of the Beskids Mountains, and the Dunajec and Poprad Valleys [2,3]. 
Nowy Sacz, which is currently a medium-sized town [4], is one of the centers organizing social and economic activity outside the influence of the largest agglomeration of Kraków-the capital of the voivodeship. Its position directly influences the development of hinterland and rural areas, including marginalized problem areas: the activation of rural regions is conditioned by implementing more effective support mechanisms. The historically shaped weakness of the hinterland area's infrastructure limits the possibilities of faster development and, at the same time, the ability to accept development impulses coming from the city.

Nowy Sacz, as a multifunctional center with a diversified economic structure, aspires to become a local activity center due to its strong position in the region. It results from a significant demographic potential, the role of a center of employment concentration (satisfying the needs of both the town's and region's inhabitants), a large number of higherlevel services, and the highest civic activity in the province. The advantage of Nowy Sacz is, therefore, its above-average development potential, especially in the broadly understood services and trade sectors [2,3]. The insufficient intensity of transport connections in the functional area of Nowy Sacz, however, prevents the city's development potential and operational area on the supra-local level to be fully released [4].

The choice of medium-size cities for comprehensive support with the development policy is connected to the fact that they play a significant stabilizing role in the polycentric settlement system $[5,6]$. The proper formation and functioning of that system positively influences territorial cohesion, reduces development disproportions and tendencies for excessive concentration, lowers activity costs, increases the probability of synergy effects, weakens negative feedback, and enables complementary network cooperation $[7,8]$. Polycentric systems are, therefore, more competitive and efficient $[9,10]$. Of course, Nowy Sacz, as a developing city, experiences numerous problems: uncontrolled urban sprawl; an inefficient public transport system; environmental pollution; the threat of mountain floods; and emigration [2].

The space syntax method was used to confirm the hypothesis that Nowy Sacz can be perceived as a growth center. It determines the strengths and weaknesses of the city. The space syntax method is used by many researchers. The state of the research concerning the problems addressed in this article is presented.

The issue of participation of models and simulations in urban design and strategic planning in the context of space syntax was raised by Yamu and Voigt (2011) [11]. The authors described opportunities and facilitators for gaining insight into previously inaccessible parameters, supporting raising awareness among audiences and decision-makers. For example, they described research for the Masterplan on Ljubljana (a large city with 290,000 inhabitants).

Regarding the use of space syntax in the current practice of historical urbanism research, Griffiths (2012) [12] and Griffiths and Palaiologou (2019) [13] stand out. They identified possible future fields of research, explored heritage issues, and understood the role of spatial configuration in the context of urban heritage studies. They brought an integrative approach, situating heritage in historical and contemporary spatial arrangements. They introduced critical reflection and a division into conservation areas, street-scale areas, and more significant spatial cultures.

Using the star model, a reading of development typologies and planning scales, and the socio-cultural and microeconomic priorities that constitute impulses for change based on syntactic properties, was presented in Friesen's (2017) [14] article. He compared two Canadian cities and contrasted syntactic analyses with a brief historical and ethnographic study of both places.

For an analytical approach to ancient city plans, an interpretation of archival materials, a methodology demonstrated through examples of nineteenth-century urban history research, and an explanation of how theory and techniques inherently designed to study architecture contribute to the study of urban and community history, see Griffiths and Vaughan (2020) [15]. 
The added value of this paper, and the need for the study, is evidenced by the fact that so far, in Poland, space syntax has been mainly the subject of theoretical research by the academic community [16], especially in the context of accessibility, with studies in large cities (with over 300,000 up to 700,000 inhabitants) such as Gdansk [17], Krakow [18], Wroclaw [19], or Lublin [20]. In addition, thus far in Poland, there has been no space syntax research on the history of 19th- and 20th-century urban planning. The issue of changes in the values of space syntax indicators concerning historical stages of urban development, especially in medium-sized cities, has also not been addressed (research gap). The current study extended the existing literature in the following way: the authors did not focus on analyzing preservation guidelines. Nevertheless, they made an extensive evaluation of historical materials. Moreover, they compared the axial structure and centrality of the layouts of the same city, but at different stages of its development, observing the transformations occurring over 200 years. Individual changes included so far in written studies by historians and art historians were presented in graphic form, taking into account urban indicators and issues of spatial configuration. In addition, the subject of the study was a medium-sized urban organism, where specific processes are much more visible and more accessible to abstract.

The study aimed to achieve the expected outcomes:

1. Construction of model solutions and urban matrix typologies of Nowy Sacz;

2. Presentation of the model logic;

3. Comparison of simulation results with reality and historical knowledge (academic and pragmatic approach);

4. Defining guidelines for future development of the city, based on research results

The application's goal was to explain the processes and popularize the knowledge with the help of clear visualization in space syntax visualizations [11].

This article is divided into six parts. First, following the introduction, in Section 2, we give the overview of methods and techniques that have been incorporated and provide datasets sources. Secondly, in Section 3, we describe the political background and civilizing influences to changes in the settlement structure and formation of the modern city of Nowy Sacz, Poland. Thirdly, under space syntax results in Section 4, we apply and interpret the case study results in consequent time frames. Then, in Section 5, we discuss limitations and possible further research, briefly introducing the current and potential Nowy Sacz's developmental issues. Finally, in Section 6, we conclude the consolidation of the obtained results and suggest application activities, mainly of educational and informational nature.

\section{Materials and Methods}

The research method of urban analysis based on space syntax was adopted in this study. It has an interdisciplinary character and provides an opportunity for a broader perspective on assessing the existing conditions and planned changes. The analysis dealt with the issues of urban development directions, city typologies, traffic patterns, and the location of central foci $[15,21]$. In climate change, the space syntax allows defining how spatial parameters can support or limit balanced urban transformation and sustainable mobility. Therefore, an analysis of historical maps was undertaken.

Space syntax analysis of historical maps enables the understanding of urban growth and development [15]. The resulting characterization of urban streets can be used to make and test hypotheses about urban movement in the past, points of convergence, and patterns of socio-economic activity.

Another research technique employed, Star Model (Star Chart), is a technique for viewing the city in terms of normalized angular choice (NAChoice) and normalized angular integration (NAIntegration) simultaneously, allowing the examination of what these variables mean in the context of urban spatial structure. The Star Model technique and comparisons of NACh and NAIn are typically used when comparing different urban organisms. A somewhat different and engaging approach is to compare Nowy Sacz throughout 
history - a medieval city, then at the dawn of the industrial revolution, and finally, set in the current conditions and ongoing transformation processes.

The theoretical model of the city's spatial structure is a research procedure that allows one to read the existing structures and identify the city's urban form and evaluate its potential $[11,22]$.

The different thematic layers of the model and the material (visible city) also concern the relations and spatial policies (logical city). They also allow the identification and description of values-including economic importance and defining patterns of privatesector behavior-mobility, and locational behavior (invisible city). These layers are set in specific time horizons (the fourth dimension-time) [23].

The model adopted in the study describes the layers:

1. Relationships-links between structural elements of urban matter (physical elements): functional, compositional, and logical connections between spatial components and systems;

2. Behavioral patterns-mobility, investment decisions, social participation.

The simulation method involves creating a dynamic system model that can be manipulated in time and space. A computer simulation study is a research and design tool developed very intensively over the past 30 years [21,24]. In design processes, the visual quality and compatibility of proposed solutions within the urban context are checked. On the other hand, in historical urban studies, different phases of the city's development have been recreated by computers and reconstructed based on plans, drawings, or descriptions left behind. Through simulation and modeling, knowledge is created by better understanding the behavior of a complex system such as an urban organism. During the research, the data analysis moved from descriptive (description) to qualitative (evaluation) [24].

The historical analysis of the city made it possible to identify the different phases of its development, along with the accompanying spatial conditions. The following data sources were used: the archival topographic map of Galicia from 1779 to 1783 , the archival city plan Uebersichtsplan Neu-Sandez from 1917, and the archival city plan from 1933. The current data were taken from the website of the Municipal Road Administration in Nowy Sacz. Substantive support is found in publicly available, cited studies and analyses of the Central Statistical Office, the Institute of Geography and Spatial Management, the Institute of Public Affairs of the Jagiellonian University in Krakow, the Małopolskie Regional Development Observatory (MORR) in Krakow, the Marshal's Office in Krakow, and the Municipality of Nowy Sacz.

The data were entered in an Axial Map for each time frame. The DepthMap X platform was used to obtain the results. The space syntax analysis process step by step is presented in Figure 1.

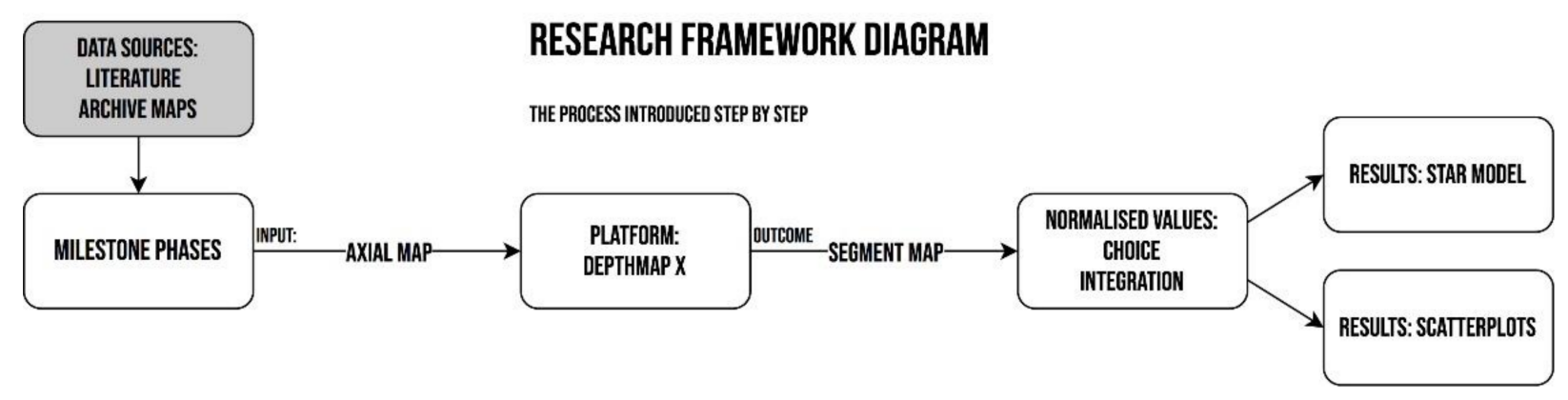

Figure 1. The research framework diagram. By authors.

\section{Analyses of Source Materials}

Changes in the settlement structure, civilization achievements, spatial policies, and the formation of the modern city directly impacted the configuration and shape of the 
urban matrix. An overview of the historical phases of city development shows this ranked as follows.

\subsection{The 18th Century}

Nowy Sacz was founded in the Middle Ages, between 1292 and 1299, and occupied a typical defensive position in the fork of the Kamienica and Dunajec rivers. The town was surrounded by a fortified wall $[25,26]$. One should remember that fortifications were one of the primary attributes of a historic European city because, since the dawn of history, the primary function of a city was to ensure the safety of its inhabitants, as security is a necessary condition for progress and development. Thus, the fortification was one of the essential city-forming factors of the past cities [27].

Nowy Sacz survived in this shape until the end of the 18th century (Figure 2). Then, the transition from a medieval to a modern town began.

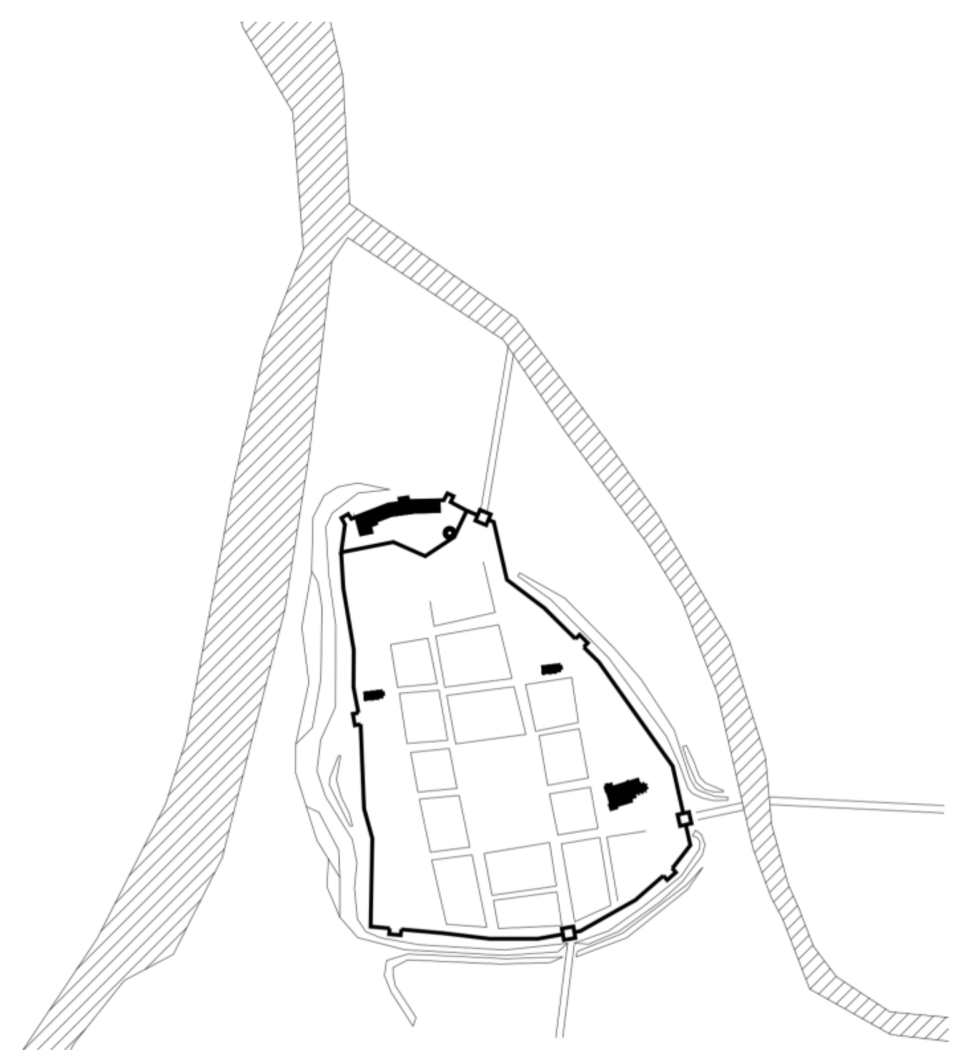

Figure 2. The medieval shape of Nowy Sacz, located in the forks of rivers; the castle, sacral buildings, and city walls are marked. By authors, based on [26].

The transformations were initiated in connection with the change in the political situation of Poland. In the Austrian partition, there was a planned action of territorial subjugation created by Emperor Joseph II. Particularly noteworthy here are the results and consequences of the colonization policy of the Austrian authorities, the forcing of brick buildings in cities, and new engineering solutions, especially road construction.

The spatial results of the colonization included new legal forms of ownership and new forms of village layout that had not been present in the area before; village colonies were delineated and built based on officially prepared plans $[25,28]$. They gave the basis for the shape of the suburbs of Nowy Sacz and the areas later incorporated into the city (Figure 3).

A distinctive element of the activities of the Austrian authorities was also the construction of roads laid out in long stretches of straight lines. In the Nowy Sacz area, the so-called "Carpathian" route was carried out, functioning as the main commercial and postal route (Haupt-Commercial-Post-oder Karpathen-Straße) [25,28]. Brick buildings were 
erected along the road: barracks and inns to serve the transit traffic. The traces of the trade road within Nowy Sacz are today's Tarnowska Street (from the north) and Jagiellonska and St. Kunegunda Streets (from the south). Krakowska and Wodna Streets were the entrances to the town from the west (Figure 4).

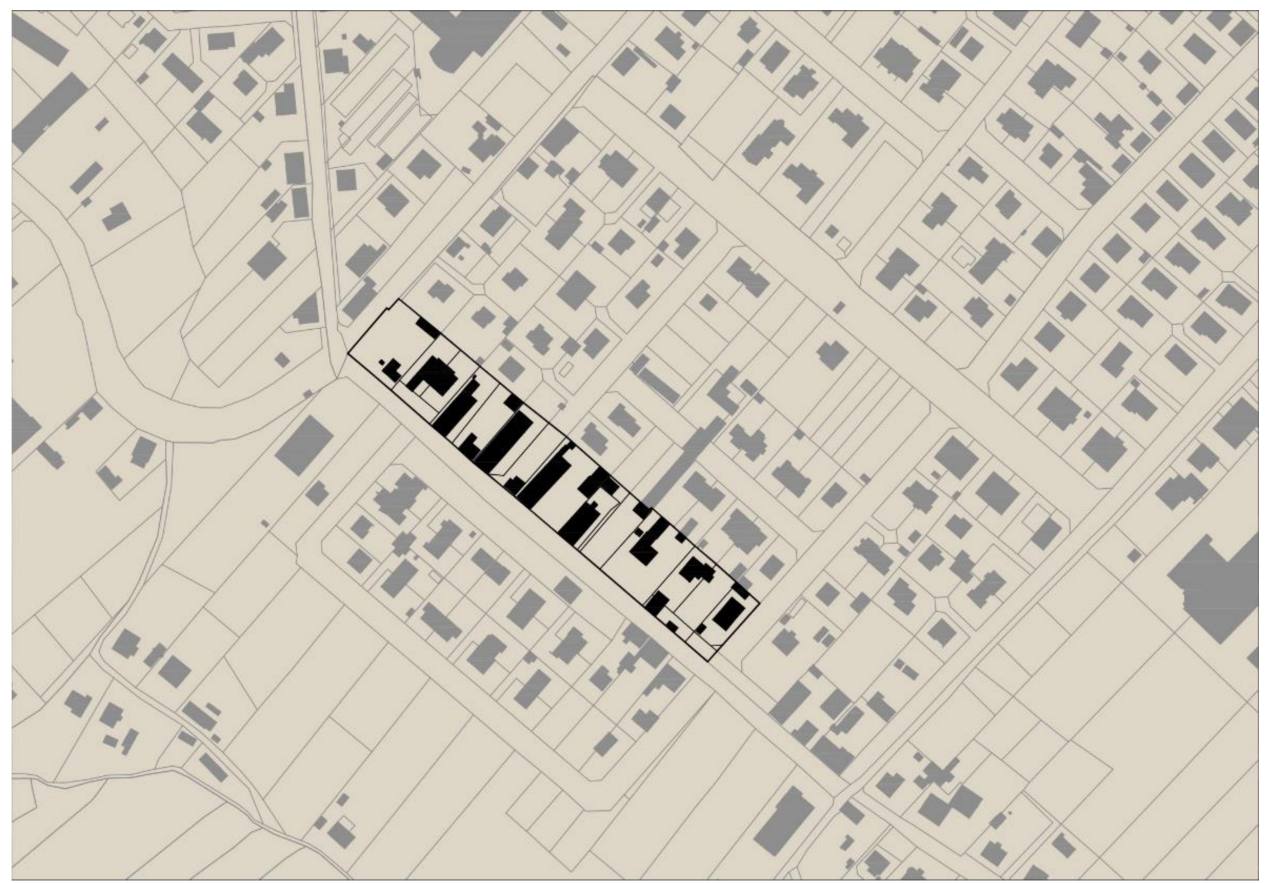

Figure 3. An example of a preserved, legible structure of one of the old colonies in the background of the contemporary buildings of Nowy Sacz. By authors, based on ([28]).

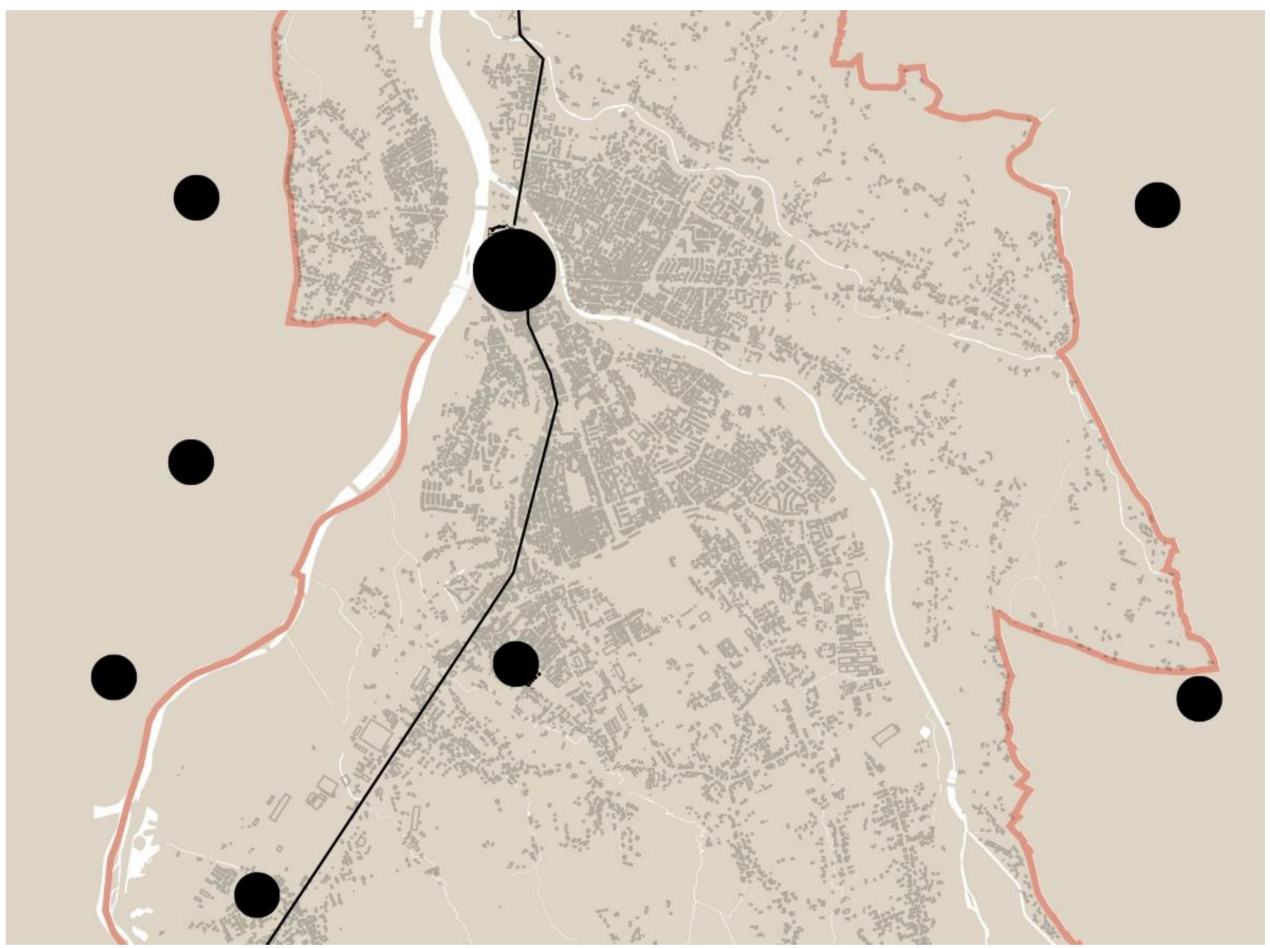

Figure 4. The structure of Nowy Sacz at the end of the 18th century did not differ much from the medieval one; the trade route and satellite settlements of the colonists are visible, shown against the background of the contemporary administrative borders of the town, and bordered by a red line. By authors, based on ([28,29], map by Mieg). 


\subsection{9th Century}

The basic guidelines in urban planning and architecture were included in the resolution of the City Council of 1870. It divides the city space into three zones: the central one, corresponding in principle to the medieval city; an additional one that includes the historical suburbs; and an external one [29].

The railroad line from Tarnów to Budapest, running along the edge of Nowy Sacz and completed in $1876[29,30]$, became a crucial city-creating factor that determined the shape of the modern city.

In 1890, the authorities adopted a twelve-meter width for newly laid out streets (which allowed them to be treated as avenues). Paradoxically, the city's fire in 1894 created new development opportunities; this event caused the expansion of permanent brick buildings and introduced urban planning regulations. An impressive urban plan is Stefan Batory Avenue, a monumental—on the scale of a medium-sized city-artery connecting the historic center with the railroad station, which was formed through the efforts of the city authorities back in 1875-1876 (Figure 5). Modern green areas in the form of public parks were developed [29].

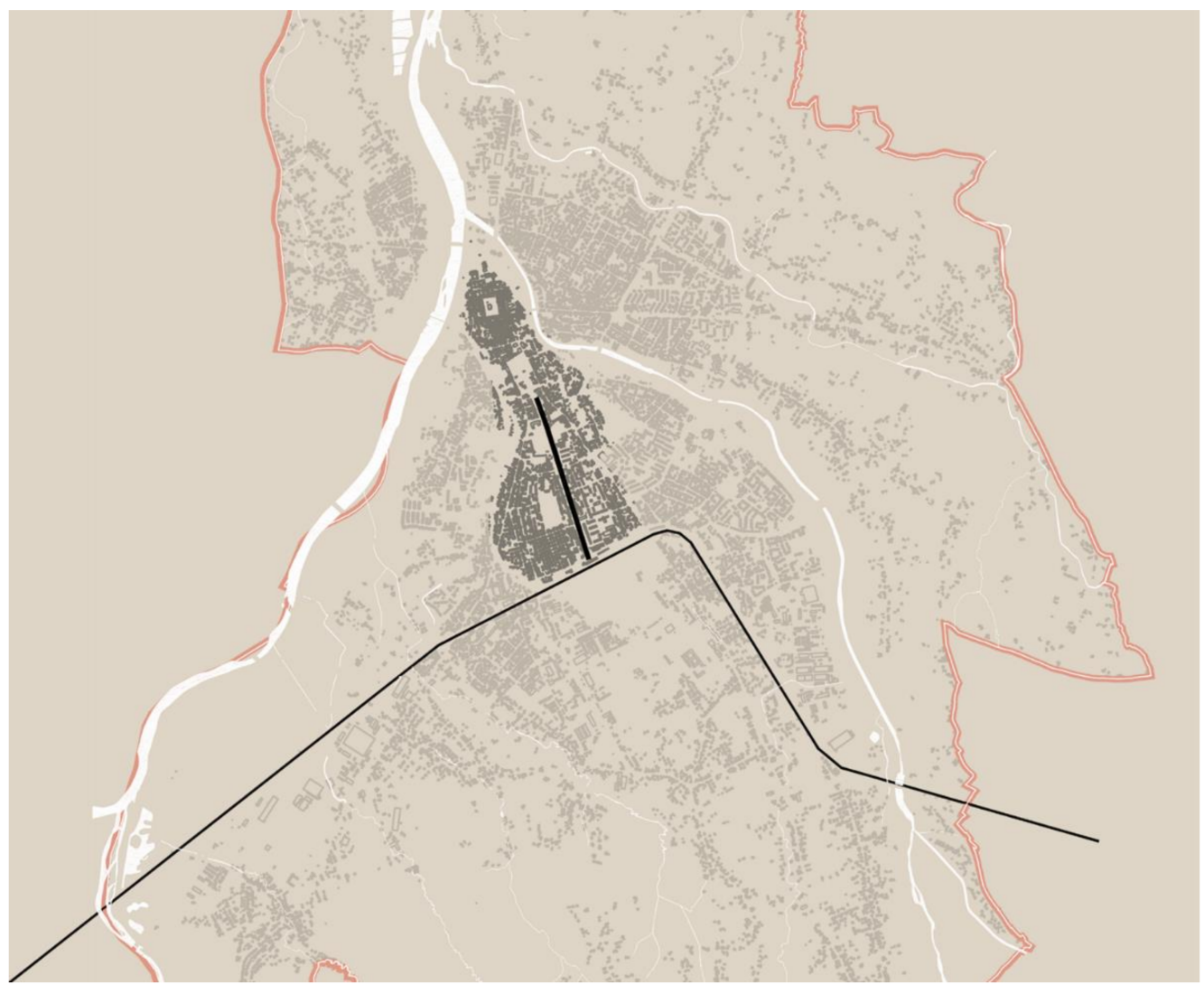

Figure 5. The building structure of Nowy Sacz at the turn of the 19th and 20th centuries; the visible expansion of the building development toward the railroad station; the east-west route of the railroad line, and the monumental Batory Avenue artery are marked. Shown against the background of the contemporary administrative borders of the city, they are bordered by a red line. By authors, based on (Uebersichtsplan von Neu-Sandez, [29,30]).

The development of the Nowy Sacz railroad junction and the accompanying repair shops resulted in creating a modern railroad colony, close to the concept of a garden city. The buildings of the colony occupied an area of about 10 hectares. It consisted primarily of two-family houses with gardens. In addition, several four- and multi-family residential buildings and public utility buildings were erected: St. Elizabeth's Church, the Workers' 
House, a bathhouse, a medical clinic, and two elementary schools (Figure 6). The colony was completed from 1892 until the outbreak of war in 1914 [30].

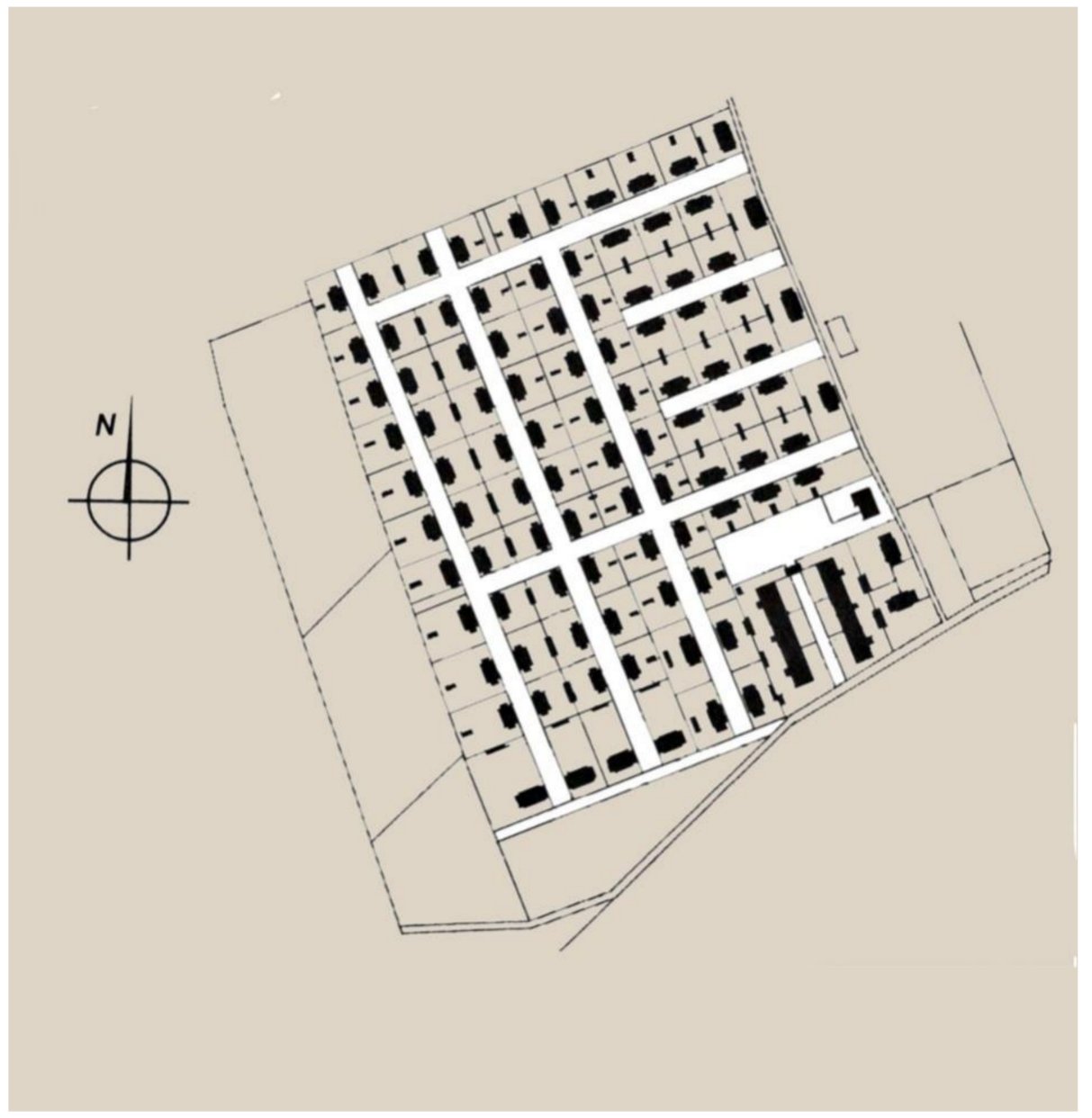

Figure 6. The structure of the railroad colony and the network of internal streets serving it. By authors, based on [30].

\subsection{0th Century and Contemporary Times}

The relatively rapid population growth (from ca. 30,000 to 35,000 just after World War II to the current 83,000 residents) and territorial expansion of the city did not bring about commensurate and desirable effects within the Old Town. Significantly few changes were made in the transport system, which maintained the central function of the Market Square (Figure 7). The natural desire to improve housing standards resulted in the outflow of young people to new neighborhoods and the "aging" of the population [31].

Significant industrial development after World War II brought many undesirable sociological, ecological, and spatial effects. Housing needs for the immigrant workforce exploded and were met by prefabricated apartment block construction [2,31].

Intensive suburbanization occurring since the system transformation in Poland (after 1989) has become an important factor affecting both metropolitan areas and smaller towns such as Nowy Sacz (a subregional center) [4]. Many institutions and commercial, financial, and service outlets have entered the Old Town, attracting customers and clients-and with them, intensive car traffic and parking needs. These are difficult to satisfy in the existing and unmodernized transport system (Figure 8). Added to this, the traffic generated by visitors and tourists coming to and passing through the city causes-especially during the holiday and winter seasons-additional congestion on the already overburdened transportation routes [31]. 


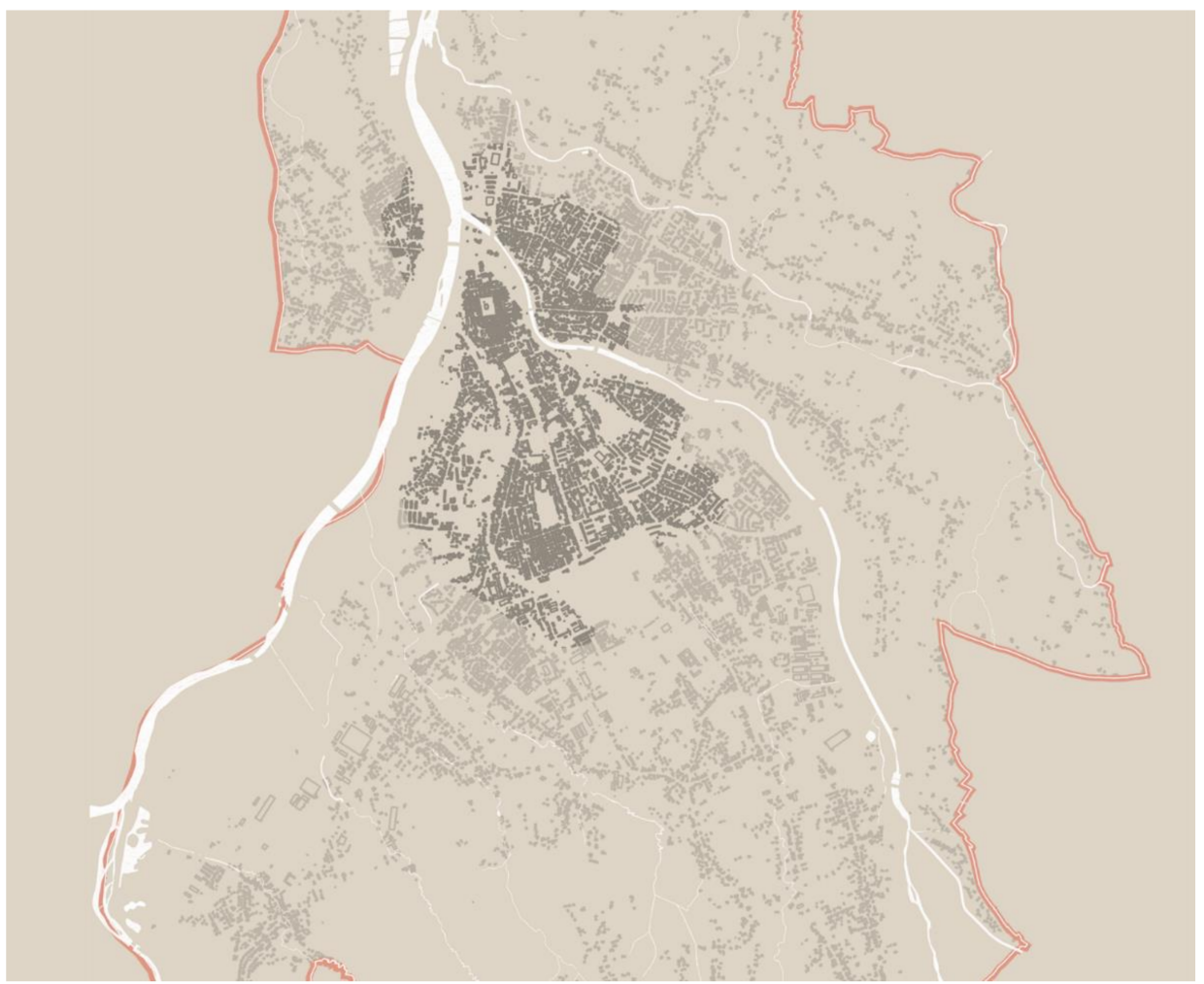

Figure 7. The structure of Nowy Sacz in the 20th century; further expansion of the built-up area and absorption of the neighboring villages is visible. Shown against the background of the contemporary administrative borders of the city, it is bordered by a red line. By authors, based on [city map 1933].

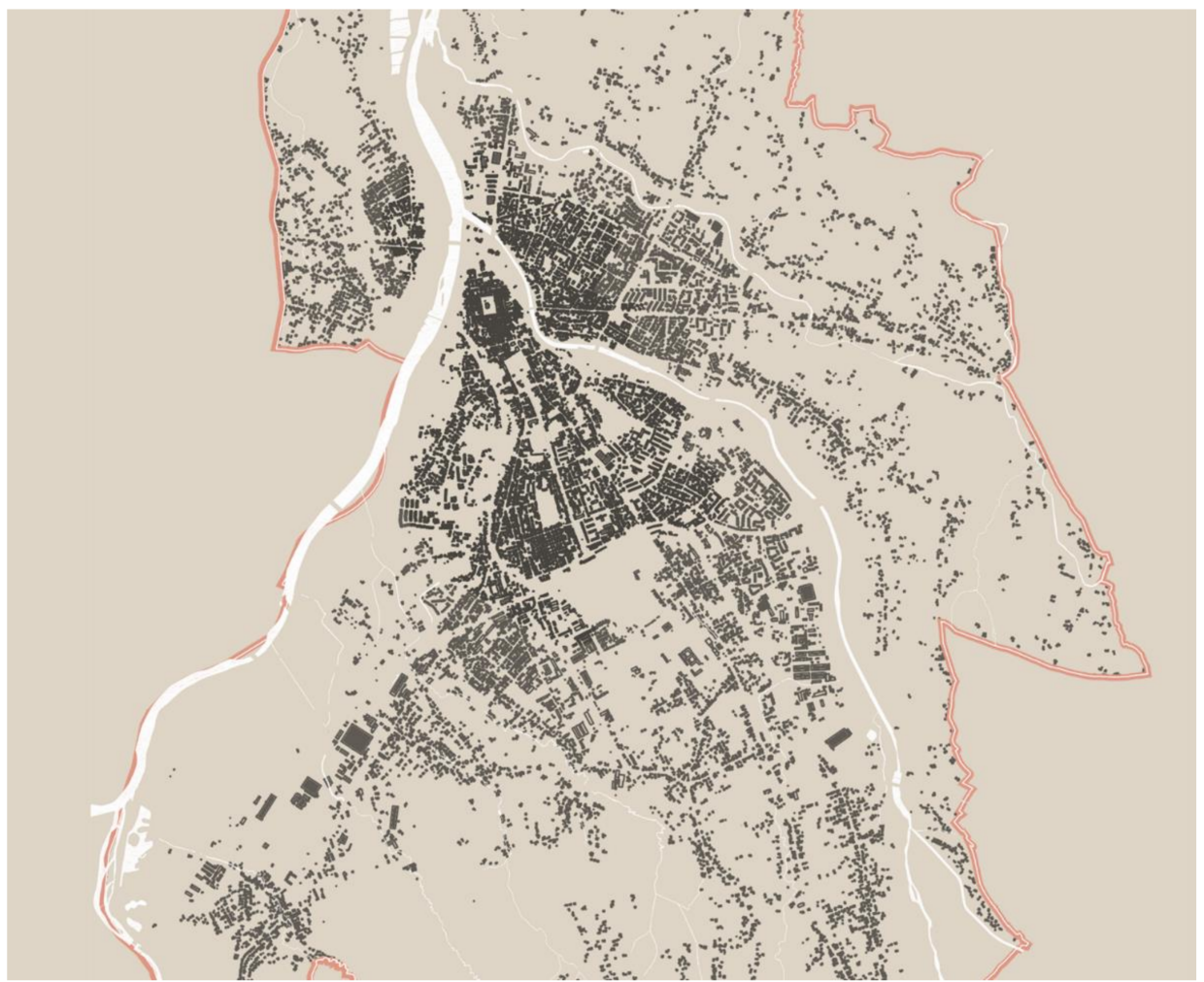

Figure 8. The structure of Nowy Sacz in the 21st century; noticeable is the considerable dispersion of the suburbs along the exit routes. The red line marks the present administrative borders of the city. By authors, based on [city map 2020]. 


\section{Space Syntax Results}

The study used space syntax theories and methods to examine the socio-cultural dimensions embedded in spatial systems of historical significance [15].

The study was based on the habitual — known from the source literature, historical accounts, and observations-foci of urban activity of a centralizing character and attractors generating traffic. These were at various stages of city development:

- $\quad$ Public buildings (temples, administrative centers, i.e., the city hall and railroad station);

- $\quad$ Public spaces (market, market squares, shopping streets, and city parks);

- $\quad$ Structures of former colonist settlements around the city;

- Or, finally, entire areas (the industrial zone of the railroad workshops).

Axial maps of the street network were drawn from current and historical city plans. Integration and Choice variables were measured for each stage of the city's spatial development. It is assumed that Integration represents the potential for space to "to-movement," which can be understood in terms of movement and flow through the city as a destination decision made at the point of departure. In contrast, Choice represents the potential of space for "through-movement," which corresponds to the choice of route, i.e., the sequence of urban spaces through which one must pass [22]. Angular Choice analysis depicts the urban streets' hierarchy. The data are included in Table 1.

Table 1. List of variables used in the model.

\begin{tabular}{cccc}
\hline Variable & Scale & Description & Measure \\
\hline $\begin{array}{c}\text { Max value } \\
\text { Normalized Angular Integration } \\
\text { (NAIn, } \mathrm{R}=n \text { ) }\end{array}$ & Global/macro & $\begin{array}{c}\text { Infinite radius (city scale), } \\
\text { movement-to potential }\end{array}$ & numeric \\
$\begin{array}{c}\text { Mean value } \\
\text { Normalized Angular Integration } \\
\text { (NAIn, } \mathrm{R}=n \text { ) }\end{array}$ & Global/macro & $\begin{array}{c}\text { Infinite radius (city scale), } \\
\text { movement-to potential }\end{array}$ & numeric \\
$\begin{array}{c}\text { Max value } \\
\text { Normalized Angular Choice } \\
\text { (NACh, } \mathrm{R}=n \text { ) }\end{array}$ & Global/macro & $\begin{array}{c}\text { Infinite radius (city scale) } \\
\text { flow potential }\end{array}$ & numeric \\
$\begin{array}{c}\text { Mean value } \\
\text { Normalized Angular Choice } \\
\text { (NACh, } \mathrm{R}=n \text { ) }\end{array}$ & Global/macro & $\begin{array}{c}\text { Infinite radius (city scale) } \\
\text { flow potential }\end{array}$ & numeric
\end{tabular}

As mentioned above, the 18th-century merchant route along the river valley gave rise to several modern city streets. Figure 9 shows the graphical results of the DepthMap X analysis. The red color indicates the segments with high values and potential (and the blue color indicates those with the lowest). The results indicate a high degree of integration of the commercial road with the entire network. This is due to the fact that it was the central axis of the system.

The railroad line became an important city-creating factor. An impressive monumental artery connects the historic city to the railroad station. The survey results shown in Figure 10 confirmed that this was an important direction. However, the artery itself was less integrated compared to the two streets parallel to it. The one on the eastern side was a trace of an old merchant route. It additionally connected the newly established railroad workers' colony. Based on this new development axis, a modern railroad workers' colony was established, in line with the garden city concept. 


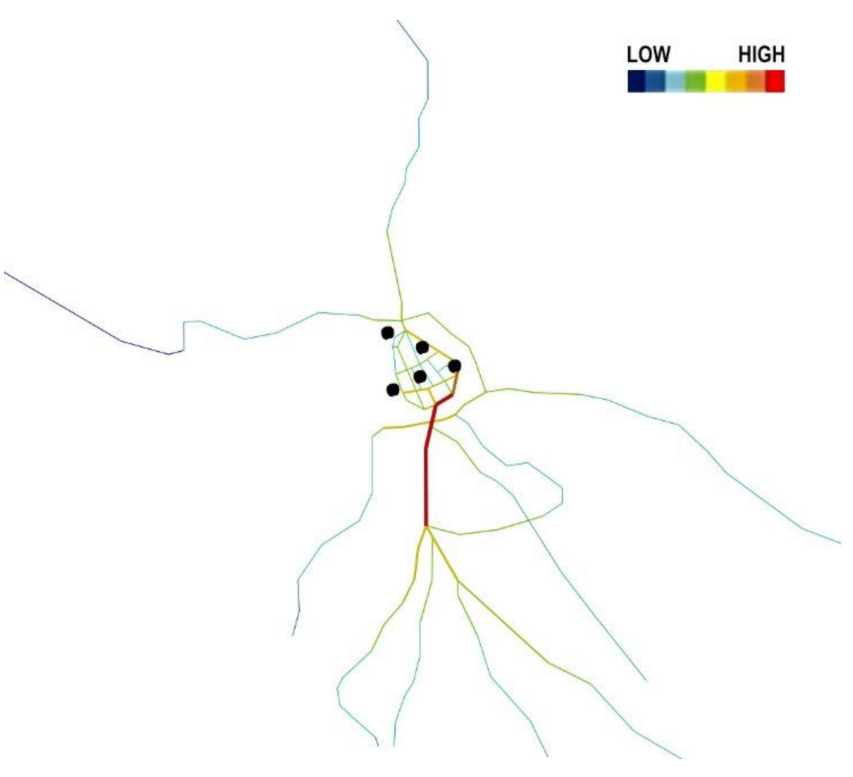

(a)

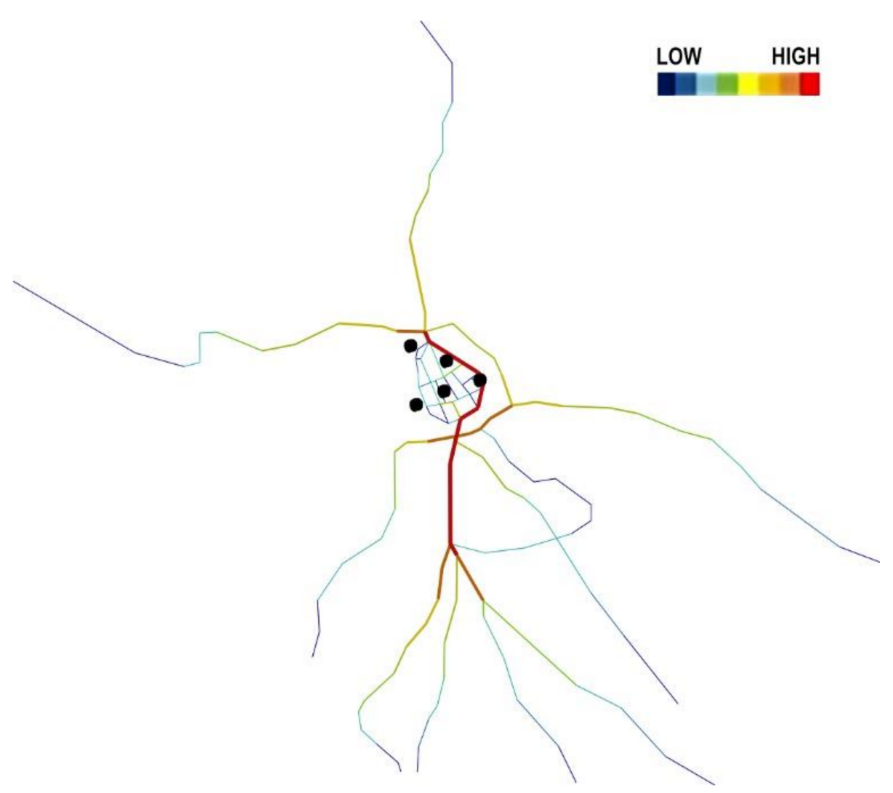

(b)

Figure 9. Values of the Integration (a) and NAChoice (b) variables for the 18th-century Nowy Sacz; still legible compact network of medieval streets within the city walls and few transit roads; the merchant tract encircling the walls and running southward was the main axis of layout and gradual expansion. By authors.

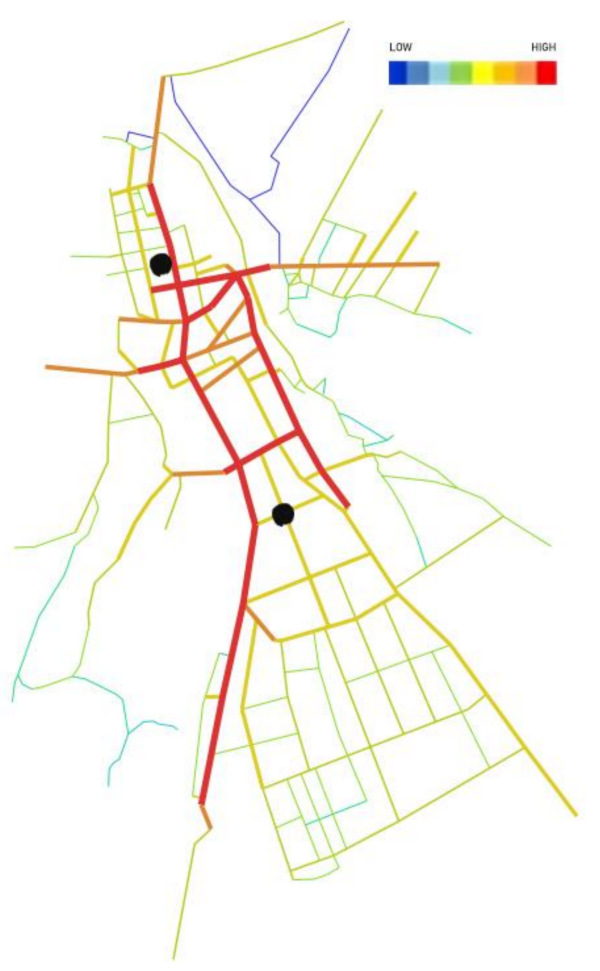

(a)

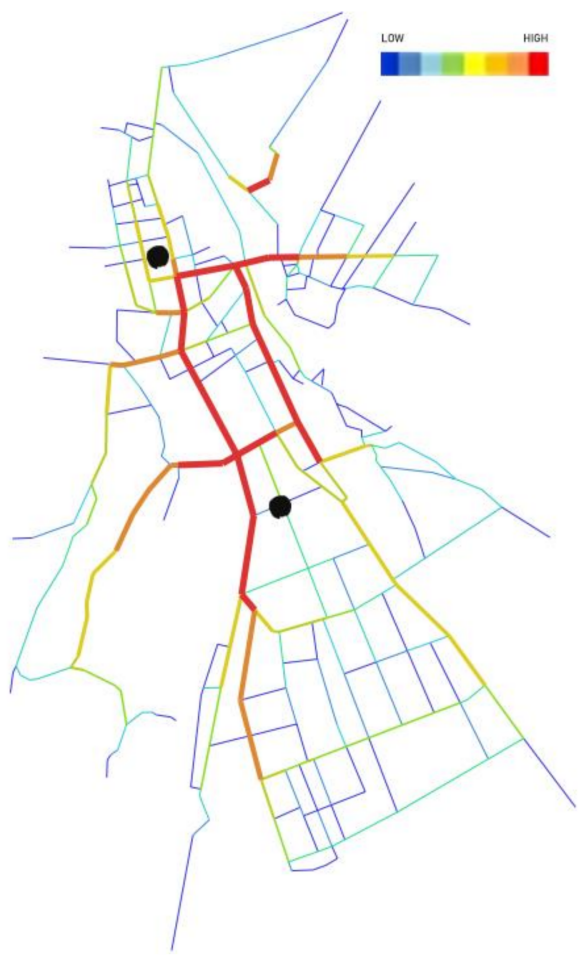

(b)

Figure 10. Values of the Integration (a) and NAChoice (b) for the 19th-century Nowy Sacz demonstrate the clear role of the railroad station location and the streets leading to it. Still important for the whole layout is the axis of the merchant tract. By authors.

Further spatial development was based on incorporating the areas of the neighboring communes, in the post-war period-by building large multi-family housing complexes. The results of the study of this stage of development are shown in Figure 11. In addition to 
the two strongly integrated axes, continuing the existing north-south gravitational system, another axis connects the growing suburbs from the east.

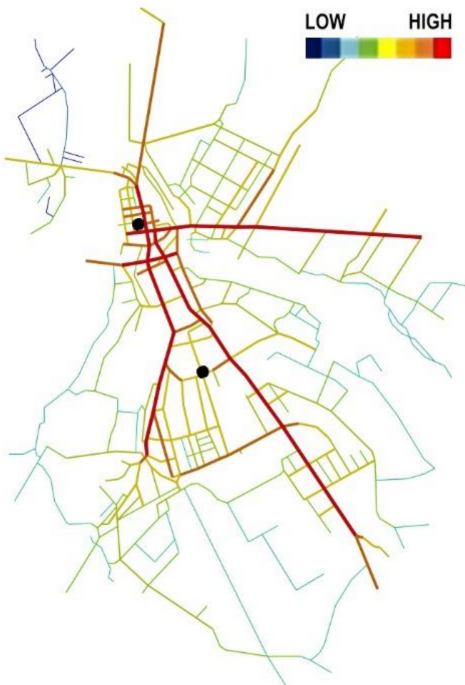

(a)

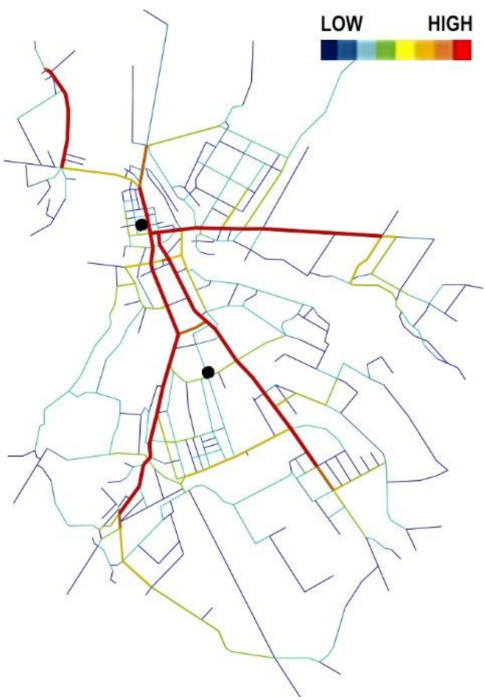

(b)

Figure 11. Values of the Integration (a) and NAChoice (b) for the 20th-century Nowy Sacz; a clear axis of the former trade route and axis leading toward the railroad station. By authors.

Currently (2021), the strongly integrated axes of historical development are still valid. The result of the study for the current state is shown in Figure 12: a former commercial tract, an artery connecting the city center to the railroad station, and a connector of the eastern suburbs. The analysis of the existing state shows that one more strongly integrated street was added - a small ring road, connecting the quadrant of the suburbs.

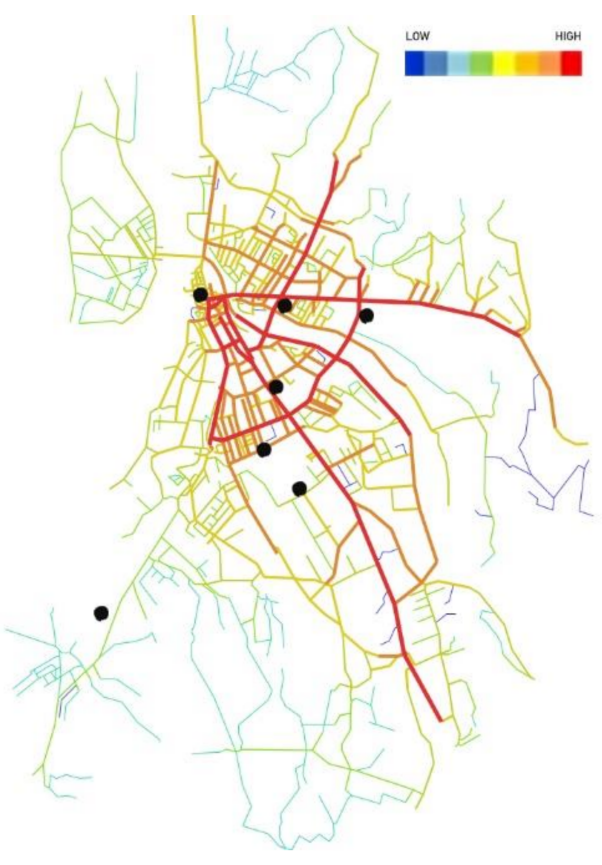

(a)

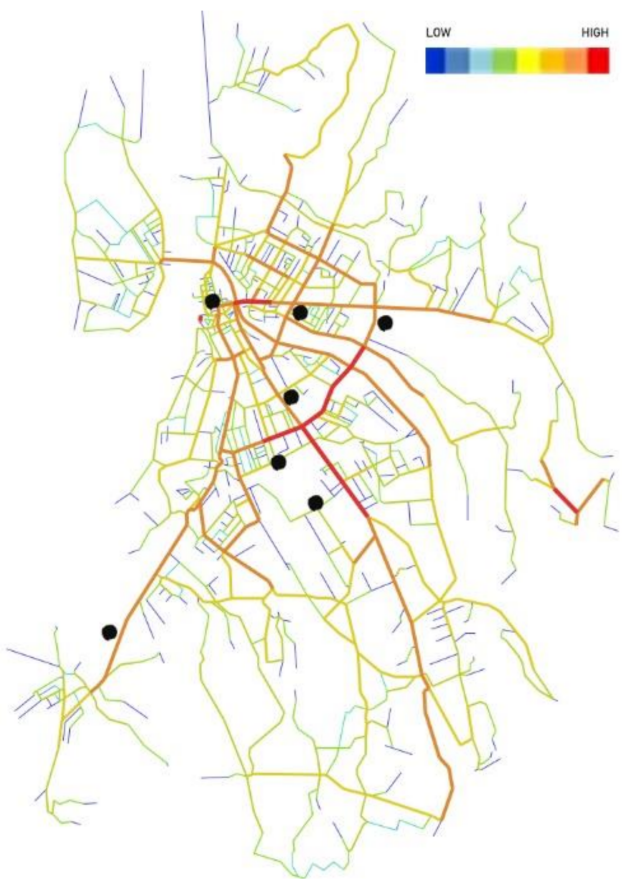

(b)

Figure 12. Values of the Integration (a) and NAChoice (b) variables for the current state of Nowy Sacz; the layout of the network of connections is the result of historical, centuries-old layers. The orientation toward vehicular communication is also visible. By authors. 
Scatter plots, also called a correlation matrix, were generated with the help of the DepthMap X program. They show the relationship between the values of normalized angular integration (NAIn) and the values of normalized angular choice (NACh). A radius of $n$ (infinite) was assumed for all variables. Both Integration and Choice take into account the centrality attribute of the structure. There are a few unusual cases, the so-called outliers. The plot included in Figure 13a shows little scatter and significant agreement between the two coefficients, and there is a strong correlation that defines a higher use of space and movement of people in public space. The plot in Figure 13b shows significantly lower correlation.

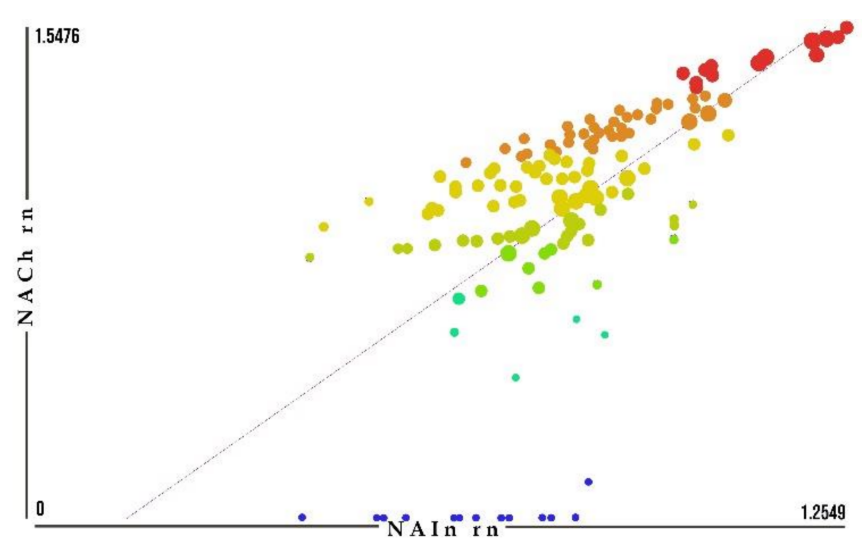

(a)

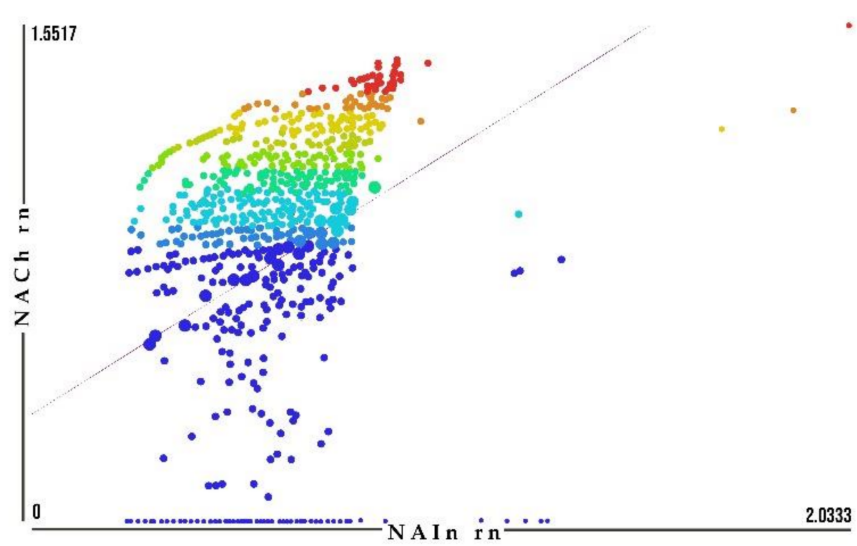

(b)

Figure 13. Correlation matrix for NAIn and NACh variables: (a) graph for the 19th-century structure; (b) graph for the contemporary, 21st-century structure. By authors.

The generated values of the NAChoice and NAIntegration variables are presented in Table 2. The comparison of values for particular stages of Nowy Sacz's development and the calculation of the so-called NACh result (which is the product of the maximum and average value) are presented in Table 3.

Table 2. The obtained values of NACh and NAIn variables $(\mathrm{R}=n)$.

\begin{tabular}{ccc}
\hline NACh & NAIn \\
\hline \multirow{3}{*}{ Max value } & $1820: 1.548$ & $1820: 1.255$ \\
& $1920: 1.474$ & $1920: 1.192$ \\
& $1933: 1.742$ & $1933: 1.941$ \\
& $2020: 1.552$ & $2020: 2.033$ \\
\hline \multirow{2}{*}{ Mean value } & $1820: 0.984$ & $1820: 0.832$ \\
& $1920: 0.870$ & $1920: 0.772$ \\
& $1933: 0.841$ & $1933: 0.746$ \\
& $2020: 0.826$ & $2020: 0.626$ \\
\hline
\end{tabular}

Table 3. Values comparison and NACh scores in different time frames.

\begin{tabular}{ccccc}
\hline & $\mathbf{1 8 2 0}$ & $\mathbf{1 9 2 0}$ & $\mathbf{1 9 3 3}$ & $\mathbf{2 0 2 0}$ \\
\hline NAIn mean & 0.832 & 0.772 & 0.746 & 0.626 \\
\hline $\begin{array}{c}\text { NACh score } \\
(\text { NACh max } / \text { mean NACh })\end{array}$ & 1.573 & 1.694 & 2.071 & 1.879 \\
\hline
\end{tabular}

The Star Model graph for Nowy Sacz is shown in Figure 14. The high and low points on the vertical axis are the average NAChoice (high) and average NAintegration (low) for each of the city's development stages. The left and right points on the horizontal axis are their maximum NAIntegration (left) and maximum NAChoice (right). Each measure is a 
standard score varying around 0 , with a negative minimum in the middle and a positive maximum at the extreme.

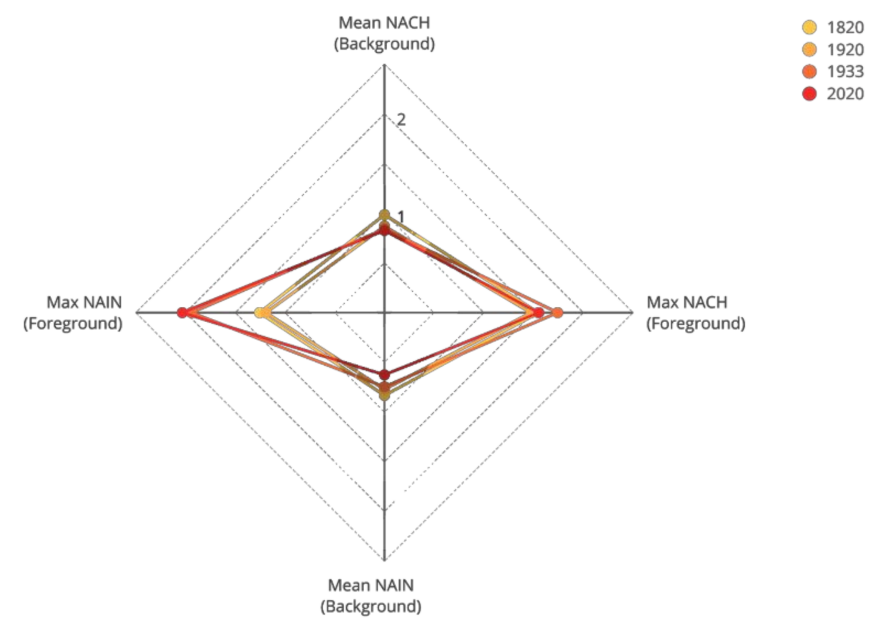

Figure 14. Star Model for NACh and NAIn values over the history of the city. By authors.

The Foreground Network is the part of the city streets' structure driven by microeconomic factors, linking centers. It benefits from maximized flow and movement. The Back-ground Network, the development of which is supported by socio-cultural factors, is reflected in the structure of the residential environment. Thus, average and maximum NAIntegration show the ease of access in the foreground (maximum) and background (average) networks in the usual syntactic sense. In contrast, average and maximum NAChoice index the degree of structure in the system: average NAChoice is the degree to which the Background Network forms a continuous grid with direct connections rather than broken into separate subareas. Maximum NAChoice represents the degree to which the Foreground Network structures the system through deformations and grid breaks [14].

Low average NAIN = socio-cultural priorities

High average NAIN $=$ microeconomic priorities

NACh result (NACh Score) $=$ maximum NACh/average NACh

Low NACh Score = planning from local to global

High NACh Score = planning from global to local

With this simple comparison, we obtain a picture of the developmental changes in the city structure, shown graphically in Figure 15.

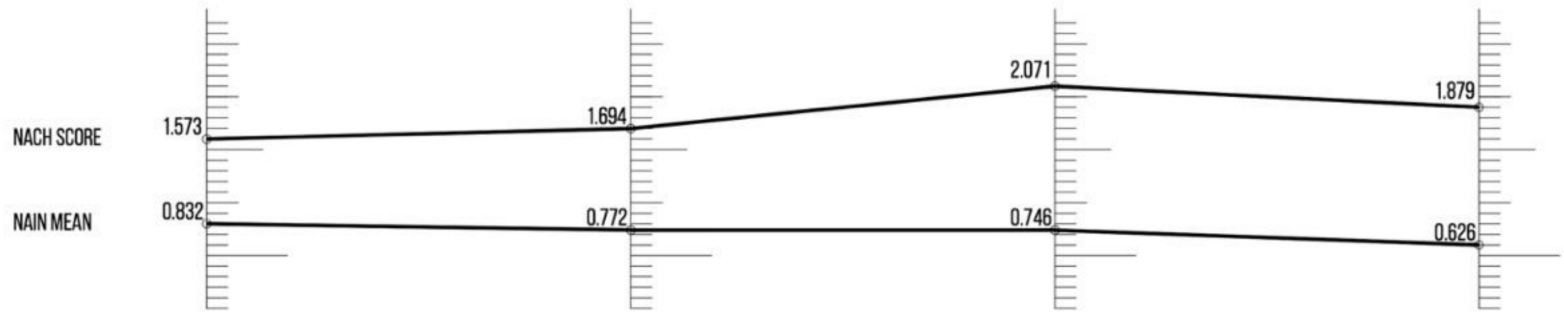

Figure 15. NACh score and NAIn Mean values throughout the history of the city. By authors. 
From the beginning of the studied period to the present day, there has been a slight but steady decrease in the mean NAIn index. This indicates a shift in priorities from microeconomic to socio-cultural factors.

On the other hand, the NACh result indicates slight fluctuations that there is nowespecially since the middle of the 20th-century-a tendency to plan from a global to a local scale. This indicates the late 20th century's priority planning framing of the "city for the car." In contrast, initially and for nearly 200 years, it was planning from the local to the global scale.

\section{Discussion}

Urban analysis gives a general picture of the study area. Weighing all the results will form the basis of the future development model and the direction of further research. As stiff action plans often cannot be put into practice, due to many circumstances beyond the control of planners, the construction of a reference model was adopted as a general strategic objective, providing orientation for all future stages of development [23]. The model based on the analysis results was developed as descriptive, allowing the identification of past and future changes based on the trends studied; and it is exploratory, examining the factors that gave impetus to past changes.

The space syntax method was used to analyze individual aspects, understanding that they provide a general explanation of the city as a phenomenon. The smaller the area considered, the more precisely it can be described. It is possible to use this method to explain phenomena that are outside the structure of perception, or that are not perceptible by the senses, such as a qualitative assessment of past planning decisions and their effectiveness decades later.

Space syntax analysis provides a link between tangible and intangible aspects of spatial culture. Understanding the role of spatial configuration in reproducing spatio-temporal events, facilitated by a graphically legible form, allows us to move away from the traditional typology of the built environment, defined only in terms of stylistic periodization [15]. In the context of urban heritage studies, this means looking at the built environment as an element of emerging arrangements of social spaces, which indeed completes the research gap and the emerging picture of urban studies of past centuries. It is also the first approach to analyze the spatial development of Nowy Sacz using the space syntax method.

An urban scientific analysis is based on the evaluation and interpretation of specific values. The resulting measurements were interpreted by comparing them with measurements from other time frames in the same area. The degree of generalization of the data makes it impossible to scientifically investigate the interaction of all active values in urban space. However, individual aspects can be accurately described, as the model's accurate measurements and relative weights are available. If we were to point out the study's limitations, the space syntax method was criticized for the absence of third-dimension data and its failure to consider attractors, such as urban nodes, anchor buildings, or public transportation hubs. Another well-known limitation that can distort space syntax results is the lack of contextual knowledge. We have tried to overcome this issue by relying on in-depth historical analysis as part of the research process.

The existing transportation and traffic organization system are among the most significant barriers to transforming and making the city center more attractive. Finally developed in the 19th century, the transportation system is very "rigid" due to topographical reasons. Relatively high and steep escarpments surrounding the old city complex from the east, north, and west, and both rivers, significantly hampered and still pose a significant technical and economic problem in transforming this system more freely [2,31].

Despite the construction of a thoroughfare in the form of the Obroncow Narwiku Boulevard, which was supposed to take over the majority of the city's long-distance traffic, too much of it still passes through the Market Square and the streets diverging from it $[31,32]$. In addition, the poor street network on the western side of the city results in the limited success of attempts to relieve this traffic. On the other hand, public pressure 
and lobbying by the interested parties have so far effectively impeded almost all attempts to move traffic out of the immediate Old Town area, or to organize it in such a way as to calm it significantly [31]. The exponential growth of automobile traffic, accompanied by an increased demand for stopovers imposed on the limited transportation space, displaces or significantly limits other types of traffic: pedestrian, and increasingly popular cycling $[2,3,31]$.

The elements of the urban matrix model that give the impact-the distribution of urban activities - can be classified as urban activity corridors. The reference is made to linear spatial development elements, located along with significant flow directions. In other words, they are elements of the city's transport infrastructure (roads and streets) with accompanying buildings. Urban corridors play an essential role in integrating the city's spatial structure. The existing layout of urban corridors is built from several overlapping systems that are described in the aforementioned, individual development phases.

As a result of the space syntax analyses conducted, those elements forming the main structure of the city of Nowy Sacz were identified. One of the factors determining the position in the system would be the scale of connections with other corridors and the ability to aggregate the urban activities of different corridors, and the range of their transfer to different regions of the city. It was observed that the examined structure generated a peculiar internal hierarchical system based on the dominance of one main element. Based on the results of the space syntax study, there is a clear and strong corridor of urbanity-running north-south as a radial road. The course of this corridor is repeated practically in each iteration of the next development phase, starting from the Middle Ages (Figure 16).

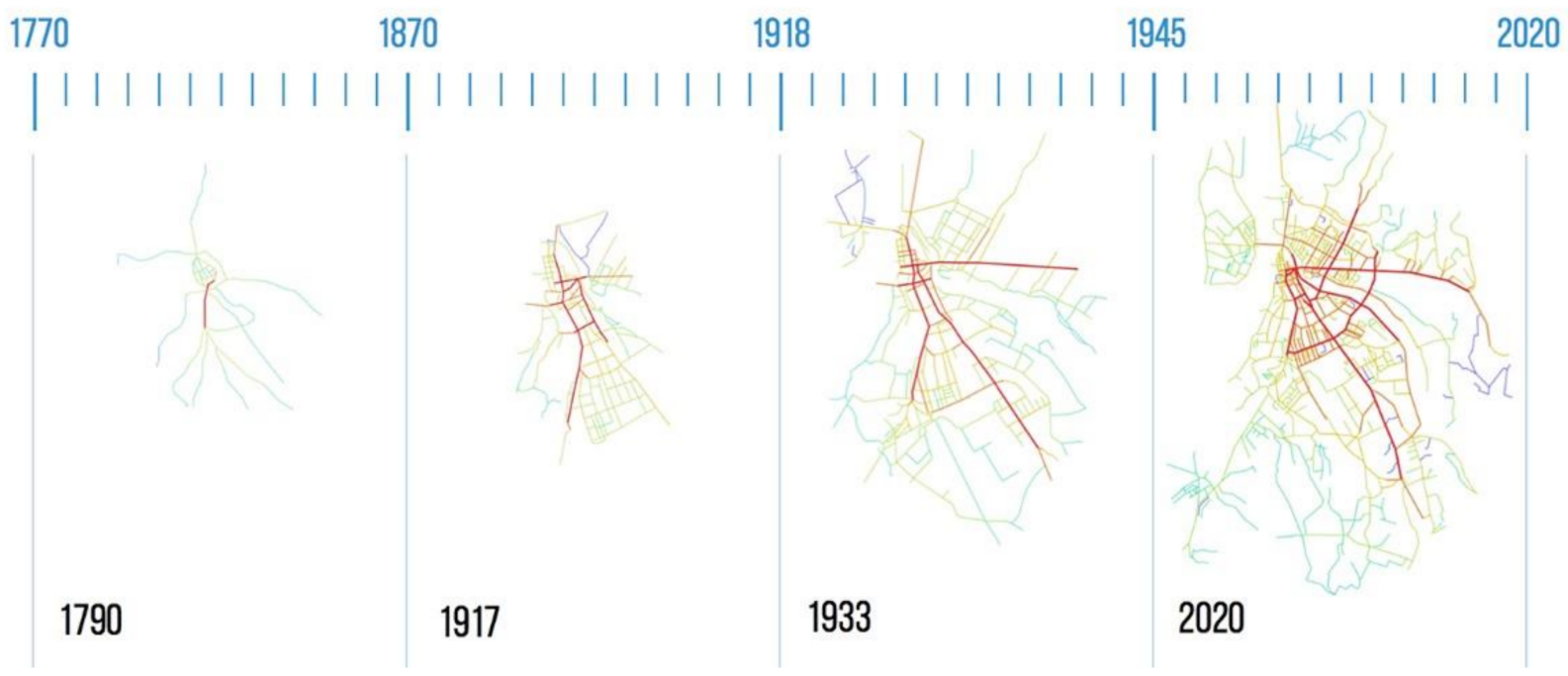

Figure 16. Values of the Integration variable for each stage of Nowy Sacz's development, placed on the conventional timeline. By authors.

The study results indicated the dominant position of the corridor based on the streets' core referred to as the "Medieval Centre-Railway Station Strip" or "North-South Strip". The projected range of development of this part of the structure may be closed from the medieval main market square on the northern side and by the railway station complex on the southern side (see Figure 5). Syntactic factors determining the prevalence of this corridor:

1. Accessibility of areas belonging to the corridor;

2. Number and importance of connections to other minor corridors;

3. High investment potential located in the corridor's girdle;

4. Integration with the network of significant public open spaces of the city center.

Therefore, from the point of view of the structure's configuration, this corridor should be strengthened. It seems valuable to densify/crystallize the structure of buildings and 
functions along the corridor. Additionally, to increase accessibility and prevent urban sprawl, the system should be enclosed with concentric ring roads.

From city documents and strategies, the three primary possible scenarios of Nowy Sacz development were estimated.

The optimistic scenario assumes optimal development conditions will occur. The city will use all development opportunities to achieve success in all priority areas. As a result of realizing the optimistic scenario, Nowy Sacz has a chance to be a coherent and spatially structured functional area, a solid subregional center. It can be a city accessible by communication, freed from heavy transit traffic, and offering high-quality public services and clean environmental resources; and through the implementation of the goals as mentioned above - a city stopping the depopulation process [2,4].

The moderate development scenario is a kind of compromise between the optimistic and pessimistic scenarios, with preservation of the current position of Nowy Sacz: development of modern transport infrastructure, especially roads; slowing down and stopping the process of suburbanization (urban sprawl); and the implementation of infrastructure projects [2].

The pessimistic scenario assumes the occurrence of the worst possible conditions of development and the risk of failure to take advantage of the opportunities, as well as the materialization of threats: increase in energy prices; shrinking resources of the local labor market; depopulation and aging of the society; segregation of urban space (ghettoization and gentrification); halt in the city development-stagnation with a threat of economic regression; the "shrinking" city syndrome-lack of new investments [2,4].

The designated revitalization areas constitute the very core of the city center. The processes taking place there and the resulting transformations of the functional and spatial structure caused by the market rules should lead to an automatic improvement in the residents' quality of life and the public space. The revitalization should focus on degraded areas in the girdles of corridors characterized by a high structure-creating, syntactic potential - which serves as vital links. Links to elements of the urban structure, especially local urbanity nodes, should be considered in the program's update for the rehabilitation of residential areas [33].

\section{Conclusions}

The research has validated the hypothesis that Nowy Sacz may be perceived as a growth center.

Space syntax methods were used to compare the relationship between the standardized syntactic descriptions of the four development stages and their corresponding spatial cultures. The two historical dialectics identified by Hillier and Hanson in their comparative work on cities and also in Friesen's work $[14,34]$ were combined into one typology. The two dimensions of this typology straddle global to local and local to global planning and socio-cultural and microeconomic preferences. The four-pointed star models of Hillier et al. place the city within this typology $[14,34]$.

Nowy Sacz, as confirmed by the results of historical analyses, has been subject to multidirectional transformations of varying intensity and on different time scales. The scenarios for predicting further social, demographic, economic, and urban changes are fraught with the risk of a prediction error-how accurately they would take many factors into account $[2,23]$.

The reached conclusions are also important for practical-application activities, which include revitalization in its broadest sense. Renewal can include all activities aimed at historic buildings and complexes, especially allocating the most valuable monuments for cultural purposes and promoting culture and cultural heritage. Along with revitalizing the material and cultural substance of the historic urban complexes of Nowy Sacz, it is advisable to carry out educational and informational activities through scientific and popular publications [2]. 
With their diverse social, historical, and architectural influences, studying existing urban structures is also an essential part of modern urban planning. Cities and neighborhoods are often marked by many generations, each with a different way of thinking. The urban fabric is characterized, among other things, by the way these many influences overlap [23].

Author Contributions: Conceptualization, F.S. and J.O.; methodology, F.S.; data curation, F.S. and J.O.; writing — original draft, F.S. and J.O.; writing — review and editing, F.S. and J.O.; visualization, J.O.; supervision, F.S.; funding acquisition-F.S. and J.O. All authors have read and agreed to the published version of the manuscript.

Funding: This publication has received financial support from the Polish Ministry of Science and Higher Education under a subsidy for science for the Faculty of Architecture at Cracow University of Technology in 2021.

Institutional Review Board Statement: Not applicable.

Informed Consent Statement: Not applicable.

Acknowledgments: The authors would like to express their gratitude to Kenita Jalivay for the proofreading of the entire text.

Conflicts of Interest: The authors declare no conflict of interest.

\section{References}

1. Haase, D.; Pauleit, S.; Randrup, T.B. Urban open spaces and the urban matrix: Elements, form and functions. In Urban Open Space Governance and Management; Routledge: London, UK, 2020.

2. City Council of Nowy Sacz. Strategia rozwoju Nowego Sacza 2020+; Załacznik nr 1 do Uchwaty Nr XIX/209/2015 Rady Miasta Nowego Sacza z dnia 29 grudnia 2015/Attachment No. 1 to Resolution No. XIX/209/2015 of the City Council of Nowy Sacz; City Council of Nowy Sacz: Nowy Sacz, Poland, 2015.

3. Prezydent Miasta Nowego Sacza. Strategia Rozwoju Nowego Sacza 2020; Prezydent Miasta Nowego Sacza: Nowy Sącz, Poland, 2008.

4. Śleszyński, P. Delimitacja Miast Średnich Tracacych Funkcje Społeczno-Gospodarcze; Instytut Geografii i Przestrzennego Zagospodarowania PAN/Institute of Geography and Spatial Planning, Polish Academy of Sciences: Warszawa, Poland, 2016.

5. Vázquez-Varela, C.; Martínez-Navarro, M. Medium-sized Spanish inland cities and regional development in the Iberian Peninsula. In Dilemmas of Regional and Local Development; Routledge: London, UK, 2020.

6. Clerici, M.A. Unity in Variety. Employment Dynamics and Specialisation Profiles of Medium-Sized Towns in the Asti-Rovigo Area, Italy (2001-2017). Quaest. Geogr. 2020, 39, 5-22. [CrossRef]

7. Adam, B. Medium-Sized Cities in Urban Regions. Eur. Plan. Stud. 2016, 14, 547-555.-555. [CrossRef]

8. Runge, A. Rola Miast Średnich w Ksztattowaniu Systemu Osadniczego Polski/The Role of Medium Towns in Development of a Settlement System in Poland; Uniwersytet Śląski: Katowice, Poland, 2013.

9. Nordregio Nordic Centre for Spatial Development. ESPON 1.1.1: Potentials for Polycentric Development in Europe; Project Report; Nordregio/ESPON Monitoring Committee: Stockholm, Sweden; Luxembourg, 2004.

10. Meijers, E.J.; Romein, A.; Hoppenbrouwer, E.C. (Eds.) Planning Polycentric Urban Regions in North West Europe, Value, Feasibility and Design; DUP Science: Delft, The Netherlands, 2004.

11. Yamu, C.; Voigt, A. Strategic Planning and Design with Space Syntax. In Proceedings of the eCAADe Conference, Ljubljana, Slovenia, 21-24 September 2011.

12. Griffiths, S. The use of space syntax in historical research: Current practice and future possibilities. In Proceedings of the 8th International Space Syntax Symposium, PUC, Santiago, Chile, 3-7 January 2012; Greene, M., Reyes, J., Castro, A., Eds.; 2012; Volume 8193, pp. 1-26.

13. Palaiologou, G.; Griffiths, S. The Uses of Space Syntax Historical Research for Policy Development in Heritage Urbanism. In Cultural Urban Heritage; Šćitaroci, M., Šćitaroci, B., Mrda, A., Eds.; Springer International Publishing: Berlin/Heidelberg, Germany, 2019.

14. Friesen, J. Star-models and urban development. In Proceedings of the 11th International Space Syntax Symposium, Lisbon, Portugal, 3-7 July 2017.

15. Griffiths, S.; Vaughan, L. Mapping spatial cultures: Contributions of space syntax to research in the urban history of the nineteenth-century city. In Urban History; Special Issue 3: Thinking Spatially: New Horizons for Urban History; Cambridge University Press: Cambridge, UK, 2020; Volume 47, pp. 488-511.

16. Deptula, M. Tradycyjne szkoły urbomorfologii a nowe podejścia do analizy miejskich form przestrzennych/Traditional schools of urban morphology and the new approaches to the analysis of urban forms. Acta Univ. Lodz. Folia Geogr. Socio-Oeconomica 2016, $25,25-38$. 
17. Marczewska, E. Określenie stopnia dostępności przestrzeni publicznych na kampusie Politechniki Gdańskiej w mysl teorii projektowania uniwersalnego z użyciem metodologii Space Syntax/Determining the degree of public space avaialability on the campus of the Gdansk University of Technology in accordance with the universal design theory using Space Syntax methodology. In Badania Interdyscyplinarne W Architekturze2, BIWA 2; Monografia Konferencyjna, Wydawnictwo Wydział Architektury Politechniki Śląskiej: Gliwice, Poland, 2017; pp. 91-102.

18. Książkiewicz, S. Modelowanie pieszej dostępności przestrzeni miejskiej w teorii Space Syntax/Modelling of pedestrian accessibility to urban space in the space syntax theory. In Miasto w Badaniach Geografów; IGiGP UJ: Kraków, Poland, 2015.

19. Saeid, A. City Boundary versus City Region within the Urban Spatial Structure of Wroclaw. In Badania Fizjograficzne, seria D-Gospodarka Przestrzenna; PTPN: Poznań, Poland, 2010; pp. 63-76.

20. Kocki, W.; Kwiatkowski, B. Space Syntax w strukturze komunikacyjnej Lublina/Space Syntax in communication structure of Lublin. Bud. i Archit. 2016, 15, 201-211. [CrossRef]

21. Groat, L.; Wang, D. Architectural Research Methods; John Wiley \& Sons: New York, NY, USA, 2002.

22. Hillier, B.; Yang, T.; Turner, A. Normalising least angle choice in Depthmap-and how it opens up new perspectives on the global and local analysis of city space. J. Space Syntax. 2012, 3, 155-193.

23. Schwalbach, G. Basics Urban Analysis; Birkhauser: Berlin, Germany; Boston, MA, USA, 2017.

24. Niezabitowska, E. Metody i Techniki Badawcze w Architekturze; Politechnika Śląska: Gliwice, Poland, 2004.

25. Krasnowolski, B. Trzy Sącze-Przekształcenia przestrzenne i sztuka. In Małopolska; Małopolski Zwiazek Regionalnych Towarzystw Kultury / Wojewódzka Biblioteka Publiczna w Krakowie: Kraków, Poland, 2017; Volume 19, pp. 11-40.

26. Widawski, J. Miejskie Mury Obronne w Panstwie Polskim do Poczatku XV Wieku; Wydawnictwo Ministerstwa Obrony Narodowe: Warszawa, Poland, 1973.

27. Weber, M. Die Stadt. In Max Weber Gesamtausgabe; Mohr Siebeck GmbH \& Co. KG: Tubingen, Germany, 1999.

28. Cepil, M. Kolonizacja józefińska na obszarze dawnej Galicji w świetle uwarunkowań prawno-osadniczych/Josephine colonization in the territory of Galicia in the light of legal and settlement conditions. Piotr. Zesz. Hist. 2020, 21, 27-44.

29. Krasnowolski, B. Z badań nad urbanistyką i architekturą Nowego Sącza w okresie autonomii galicyjskiej/From the research on urbanization and architecture of the town of Nowy Sacz at the time of Galician Autonomy. In Rozwój Przestrzenny Miast Galicyjskich; Beiersdorf, Z., Laskowski, A., Eds.; Regionalny Ośrodek Studiów i Ochrony Środowiska Kulturowego: Jasło, Poland, 2001.

30. Śliwiński, W. Kolonia kolejowa w Nowym Saczu—zabytkowe osiedle robotnicze z końca XIX wieku/Railway housing estate colony in Nowy Sacz-A workers quarter from the end of the 19th century as a monument of town-planning. In Rozwój Przestrzenny Miast Galicyjskich; Beiersdorf, Z., Laskowski, A., Eds.; Regionalny Ośrodek Studiów i Ochrony Środowiska Kulturowego: Jasło, Poland, 2001.

31. Invest Bau Consulting Team. Nowy Sacz-Koncepcja rewitalizacji obszaru Starego Miasta. In Opis Zalozen i Propozycji Rozwiazan Progamowych i Funkcjonalno-Przestrzennych, Competition Entry No. 491104; Wroclaw, Poland, 2003.

32. van Nes, A. The Impact of the Ring Roads on the Location Pattern of Shops in Town and City Centres. A Space Syntax Approach. Sustainability 2021, 13, 3927. [CrossRef]

33. Bandarin, F.; Van Oers, R. (Eds.) Reconnecting the City: The Historic Urban Landscape Approach and the Future of Urban Heritage; Wiley: West Sussex, UK, 2014.

34. Hillier, B.; Hanson, J. The Social Logic of Space; Cambridge University Press: Cambridge, UK; New York, NY, USA, 1993. 